\title{
A study of commonly occurring fungal diseases on stored tomatoes of Kathmandu Valley
}

\section{Shakya $\mathbf{B}^{1}$ and Aryal HP ${ }^{2}$}

${ }^{I}$ Natural History Museum, Tribhuvan University, Swayambhu, Kathmandu, Nepal

${ }^{2}$ Central Department of Botany, Tribhuvan University, Kirtipur, Nepal

Shakya B, Aryal HP 2021 - A study on some fungal diseases on stored tomatoes of Kathmandu Valley. Studies in Fungi 6(1), 159-167, Doi 10.5943/sif/6/1/9

\begin{abstract}
Fungal pathogens destruct the quality and quantity of tomato production and cause health hazards to the consumers as well as economic loss to the traders. This study was carried out to identify some fungal diseases associated with post-harvest deterioration of stored tomato fruits in three vegetable markets of Lagankhel, Balkhu and Kalimati of Kathmandu Valley. The samples were collected from selected sites in three separate trials and cultured in Potato Dextrose Agar. During investigation, 16 species belonging to 15 genera of fungi were identified. They were Alternaria alternata, A. solani, Aspergillus niger, Botrytis cinerea, Cladosporium fulvum, Colletotrichum truncatum, Curvularia tetramera, Fusarium oxysporum, Geotrichum candidum, Mucor mucedo, Penicillium notatum, Phytophthora infestans, Phoma exigua, Pullularia pullulans, Pythium aphanidermatum and Rhizopus stolonifer. These were responsible for 15 different diseases of Alternaria fruit rot, Anthracnose, Black mold rot, Botrytis Bunch Rot, Damping off/ fruit rot, Drechslera mold, Fusarium rot, Mucor rot, Penicillium rot, Phoma blight, Phytophthora rot, Rhizopus rot, Russet, Scab and Sour rot. The presence of these fungi and corresponding rot diseases on stored tomato indicate the need for management of fungi, farm sanitation and improved market in order to prevent field-to-storage transmission of pathogens.
\end{abstract}

Key words - Consumers - Health hazards - Pathogens - Post-harvest diseases - Traders

\section{Introduction}

Tomato (Lycopersicum esculentum L.) belonging to the family Solanaceae, is an important vegetable crop all over the world. It is one of the most popular and indispensable ingredients of the human diet. The crops were originated in Western South America and Central America (Wamache 2005). Although it is widely adapted with variable climatic conditions, tomatoes are still vulnerable to a variety of diseases and infections during production, harvesting, transportation and storage. Most of the diseases are a result of fungal infections.

Tomatoes are the most consumed non starchy vegetable and are the most significant source of dietary lycopene and ascorbic acid. Tomato contains antioxidants lycopene, ascorbic acid and phenols (George et al. 2004). Lycopene is the carotenoid pigment principally responsible for the characteristic deep-red color of ripe tomato fruits and tomato products. It has attracted attention due to its biological and physicochemical properties, especially related to its effects as a natural antioxidant (Shi 2008). Lycopene being an efficient quencher of singlet oxygen and free radicals provides protection against a broad range of epithelial cancers (Mascio et al. 1989). The consumption of tomatoes also reduces the risk of cardiovascular disease, osteoporosis, and 
ultraviolet light-induced skin damage e.g. sun burn and cognitive dysfunction. Tomatoes are a great source of vitamin-carbohydrates, proteins, fats and potassium (Talvas et al. 2010).

Tomatoes are infected by several species of fungi (Alternaria alternata, Colletotrichum dematium, Phytophthora infestans, Pythium aphanidermatum, Geotrichum candidum, Fusarium oxysporum, Curvularia tetramera, Cladosporium sp., Penicillium notatum, Mucor mucedo, Botrytis cinerea, etc.), causing different diseases with distinct symptoms. They hinder the production of tomatoes leading to severe economic losses. Moreover, they can lead to serious health problem if consumed. Tomato contaminated with Fusarium species is dangerous for human health, because they produce mycotoxins (Jofee 1986, Nelson et al. 1990). Alternaria rot caused by Alternaria solani has been considered as the most prevalent disease and causes huge losses to tomato thus making tomatoes unfit for consumption (Douglas 1922). Alternaria rot caused by Alternaria solani is the main decay causing organism of postharvest tomato fruit (Agrawal et al. 1950). Rhizopus rot caused by Rhizopus stolonifer causes significant postharvest losses (Hahn et al. 2004). Fusarium rot caused by Fusarium oxysporum is reported as the most destructive on ripened tomato in the U.S. (Banyal et al. 2008). F. oxysporum can produce mycotoxin that is carcinogenic. Phytophthora rot is caused by Phytophthora infestans (Mills 1940). These postharvest losses are more severe in developing than in developed countries (Enyiukwu et al. 2014).

\section{Materials \& methods}

\section{Study area}

The study area was Kathmandu valley that lies at an altitude of approximately $1400 \mathrm{~m}$ above the sea level. It has a pleasant climate with average summer temperature of $25^{\circ} \mathrm{C}-35^{\circ} \mathrm{C}$ and $22^{\circ} \mathrm{C}-12^{\circ} \mathrm{C}$ in winter. The average annual temperature is $18.1^{\circ} \mathrm{C}$. About $1505 \mathrm{~mm}$ of precipitation falls annually (Climate Data 2020). Fruit and vegetable markets of Kalimati, Balkhu and Lagankhel of Kathmandu valley were selected as field sites due to their heavy trade and transit.

\section{Collection of samples}

The infected tomatoes were collected from three different study sites - Lagankhel fruits and vegetable market (Site A), Balkhu agriculture and fruits market (Site B) and Kalimati fruits and vegetable market (Site C) of Kathmandu valley. The material was collected within December, 2019 to March, 2020.

\section{Laboratory analysis}

\section{Isolation}

A total of 90 samples were collected from three different study sites. 30 samples were collected from each sites in 3 visits. The photographs were taken on the spot and collected samples were placed in sterilized plastic bags and brought to the Central Department of Botany, Tribhuvan University laboratory. The collected samples were deposited in the laboratory refrigerator at $4^{\circ} \mathrm{C}$. The Transverse Section (T.S.) of the infected part of the tomato was prepared and examined under the microscope for identification. For confirmation, the pathogens were separated from its host and grown in sterile culture medium. Plant pathogenic fungi were isolated by planting surface sterilized bits of the infected plants tissue on sterilized media. For surface sterilization, four sterilized Petri plates were arranged in a row near the Bunsen flame, under sterile condition of laminar air flow cabinet. In the first petridish, ethyl alcohol $75 \%$ was filled and the rest three dishes were filled with sterilized water. Small bits of infected tomato tissue were sterilized individually by placing them in ethyl alcohol for 1-2 minutes, and then transferred to sterile water in the next dish after 1-2 min. Then, they were moved to the next dish of sterile water. Thus, surface sterilized tissue was aseptically transferred on the sterilized solidified PDA medium in Petri plates with the help of sterilized forceps. 


\section{Culturing}

The Petri plates containing surface sterilized materiel on sterilized medium were incubated at $25 \pm 2^{\circ} \mathrm{C}$ for 7 days.

\section{Subculture}

After seven days, the Petri plates with fungal cultures were taken out from the incubator and photographed. Then, each 7 day old fungal culture was sub-cultured into three fresh PDA plates using the mycelial discs obtained from a cork borer. The Petri plates were sealed with parafilm tapes and kept for incubation at $25 \pm 2^{\circ} \mathrm{C}$ for $3-5$ days. The pure cultures obtained by sub-culturing were photographed.

After the separation of inoculums, rest of the culture was used to identify the pathogen.

\section{Identification}

The fungi were carefully transferred on to cello tape and mounted on the slide containing a mixture of lactophenol and cotton blue and then examined under an Olympus microscope Model No. CX22 Japan. The photographs were taken under immersion oil. The morphological characteristics of the fungi were studied under high power $(10 \mathrm{x} \times 40 \mathrm{x})$. The pathogens were identified with the help of diagnostic morphological characteristics seen under the microscope as well as by concerning standard literature, (Bessey 1950, Barnett 1960, Ellis 1971, Ainsworth et al. 1972, Arx 1974, Gilman 1998), expertise and web surfing on online data bases (such as Index Fungorum, Mycobank.org).

\section{Results}

During the investigation, 16 species of pathogenic fungi belonging to 15 genera (Fig. 1) with distinct characteristics (Table 1) were identified from three study sites of A, B and C. The fungal pathogens associated with the tomato diseases varied in each site. (Table 2). Eight species (Alternaria alternata, Alternaria solani, Aspergillus niger, Colletotrichum truncatum, Fusarium oxysporum, Geotrichum candidum, Mucor mucedo and Rhizopus stolonifer) were obtained in all three sites of A, B and C and are dominant (D), 12 species (Alternaria alternata, Alternaria solani, Aspergillus niger, Botrytis cinerea, Cladosporium fulvum., Colletotrichum truncatum, Fusarium oxysporum, Geotrichum candidum, Mucor mucedo, Pythium aphanidermatum, Phytophthora infestans and Rhizopus stolonifer) were common to site A and B. Eight species (Alternaria alternata, Alternaria solani, Aspergillus niger, Colletotrichum truncatum, Fusarium oxysporum, Geotrichum candidum, Mucor mucedo and Rhizopus stolonifer) were common to site A and C. And ten species (Alternaria alternata, Alternaria solani, Aspergillus niger, Colletotrichum truncatum, Curvularia tetramera, Fusarium oxysporum, Geotrichum candidum, Mucor mucedo, Penicillium notatum, Rhizopus stolonifer) were common to site B and C. Similarly, on the basis of frequency of occurrence, the species are categorized as eight dominant (D), six moderate (M) (Botrytis cinerea, Cladosporium fulvum, Curvularia tetramera, Penicillium notatum, Pythium aphanidermatum and Phytophthora infestans) and two rare (R) (Phoma exigua, Pullularia Pullulans) were determined (Table 2).

It is found that of 16 species, except Curvularia tetramera, Penicillium notatum and Phoma exigua all were recorded from site A, and except Pullularia pullulans all were recorded from site B, whereas 10 species (Alternaria alternata, Alternaria solani, Aspergillus niger, Colletotrichum truncatum, Curvularia tetramera, Fusarium oxysporum, Geotrichum candidum, Mucor mucedo, Penicillium notatum and Rhizopus stolonifer were obtained from site C.

Thus it is observed that, the maximum numbers of fungi were recorded from site $\mathrm{B}, 15$ species $(93.75 \%)$, followed by site A, 13 species $(81.25 \%)$ and from site $\mathrm{C}$, has least in number i.e. 10 species $(62.5 \%)$ (Table 2).

\section{Discussion}

Tomatoes were infected by different fungal pathogens, in the field, due to unmanaged market 
and fungal bio-aerosols in the market environment. Occurrence of pathogens on tomato basically depends upon the sources of tomato and the environment where they are exposed to, and also depends upon the suitable temperature and moisture to grow. Availability of fungal species are varied in different study sites. Among the 16 reported species eight species are most common and dominant (Table 2). Similar results have been reported by Rodrigues \& Kakde (2019). They mentioned that A. niger, A. flavus, A. alternata, Colletotrichum sp., Rhizopus sp. and F. oxysporum were the most common and frequently isolated. While Botrytis cinerea, Penicillium digitatum, $P$. notatum, Phoma sp., Cladosporium sp., Geotrichum candidum were isolated in the least frequency during investigation which is almost similar to the present investigation. And a similar report has also been given by Kakde \& Kakde (2012). They reported that the fungi Aspergillus, Penicillium, Cladosporium, Fusarium and Alternaria were the most frequently isolated fungi from vegetables and fruits. These fungi were the most prevalent in the commercial market and also found to be responsible for most of the decay of vegetables and fruits during storage. Hence, there may be a relationship between the prevailing fungal bio-aerosols and the spoilage diseases.

16 reported species of this investigation are responsible for 15 different corresponding diseases (Table 2). Wani (2011) reported nine fungal rot diseases on postharvest tomato. Among them seven were also seen in the present investigation. They are Alternaria rot, Anthracnose rot, Mucor rot, Blue mold rot, Phytophthora rot, Phomopsis blight, Fusarium rot caused by respective pathogen of Alternaria solani, Colletotrichum truncatum, Mucor Mucedo, Penicillium sp., Phytophthora infestans, Phoma destructiva and Fusarium oxysporum respectively. Similar to this investigation, Massoud (2013) also isolated Aspergillus, Acremonium, Alternaria, Fusarium, and Penicillium in Lycopersicum esculentum from Aswan, Egypt. Chigoziri et al. (2018) also reported Aspergillus flavus, Colletotrichum capcisi and Pythium sp. from Nigeria.

Sajad et al. (2017) studied fungi associated with the spoilage of postharvest tomato fruit in different markets of Jabalpur, Madhya Pradesh, India. They reported Sour rot, Rhizopus rot, Black mold rot, Fusarium rot, and Alternaria rot caused by respective pathogen of Geotrichum candidum, Rhizopus stolonifer, Alternaria alternata, Fusarium sp. and Alternaria solani respectively. All of these are similar to the results found in the present investigation.

Bartz et al. (2017) described 11 post-harvest fungal diseases along with bacterial postharvest diseases found in Florida. Among them, nine of the fungal rot diseases namely Fusarium, Phoma, Anthracnose, Cladosporium, Grey mold, Phytophthora, Rhizopus, Black mold and Sour rot were also found in the present investigation.

Thus, 11 fungal rot diseases of Alternaria, Anthracnose, Black mold, Fusarium, Mucor, Penicillium (Blue mold rot), Phytophthora, Pythium, Phomopsis blight, Rhizopus and sour rot were described more or less by different researchers from other countries. Kohl et al. (2015) only reported scab epidemic in Dabrowice on Cortland Apple.

The tomatoes in site $\mathrm{C}$ had been imported from outside the country, as well as obtained from local areas like Bhaktapur, Naubisae etc. They were supplied to site B and A. In site B the tomatoes were also collected from Dhading, Bajrabarahi. Likewise, in site A, they were also brought from surrounding areas like Chapagaun, Shankhamul etc. Therefore, some similarities of pathogenic fungi were seen in the dominant species in all three study sites, as they were transmitted from fields to vegetable market through wholesalers with suitable temperature for their growth. Some dissimilarity was also observed that must be due to market environment where opportunistic fungi grow.

Adhikari \& Manandhar (1997) mentioned 8 different species of fungi found on tomato bits. Similarly, Manandhar et al. (1997) reported Tolypocladium cylindrosporum including 7 more pathogenic fungi from the leaves of L. esculentum in Dhapasi of Kathmandu, Nepal. Manandhar et.al. (2017), reported 15 species of fungal pathogens from 342 tomato crop sample, along with other solanaceous crop. The sample were collected by Plant Pathological Division (PPD), National Agricultural Research Council (NARC) from fiscal year 2067/068 BS to 2071/072 BS from the different part of the country, Nepal. However, no work has been done in the field of fungal pathogens on the postharvest tomato in Nepal. And it is the first time that an opportunist fungus 
Pullularia pullulans (Fig. 10) has been mentioned which is responsible for Russet disease on tomatoes. Thus, it is the first investigation that gave a list of fungal pathogens and postharvest fungal disease of storage tomato in Nepal.

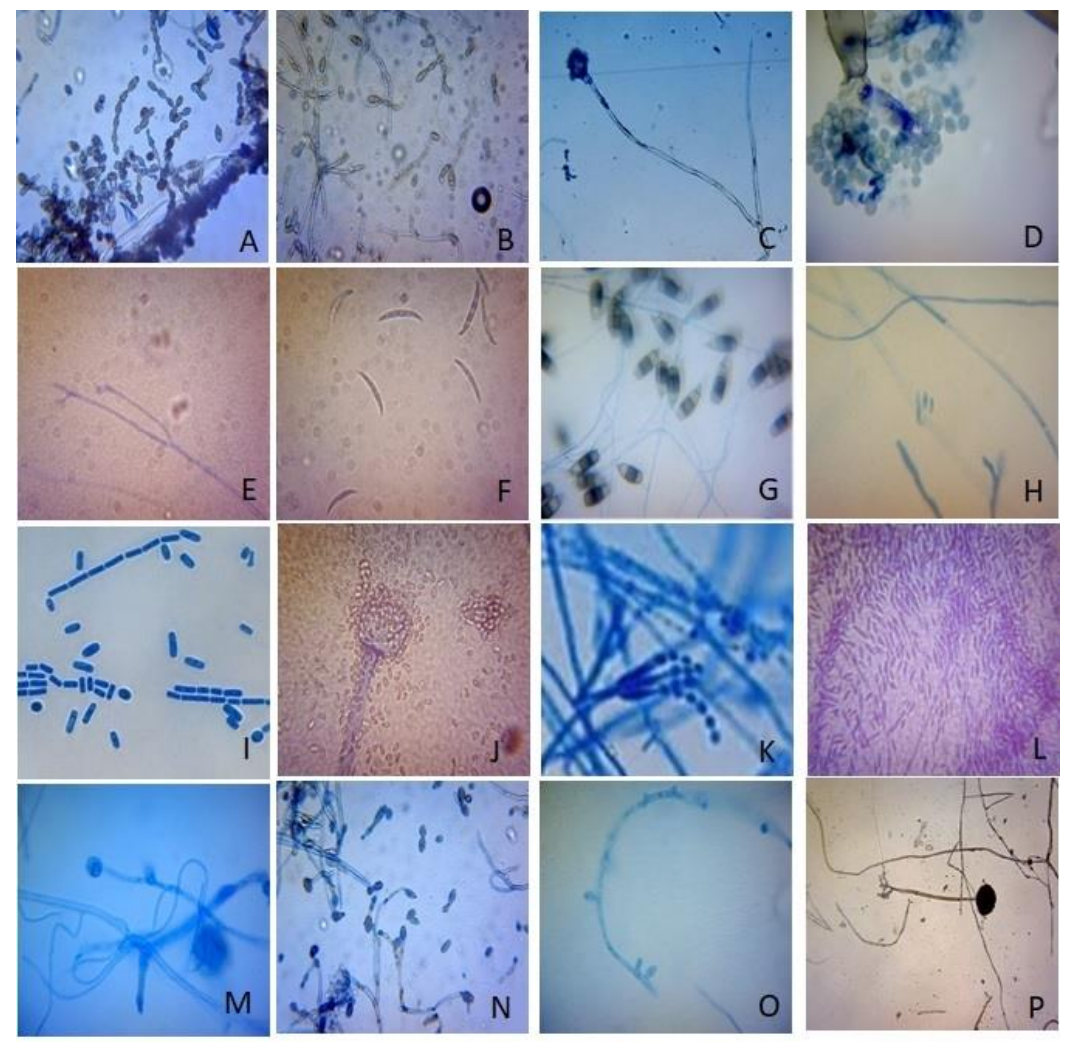

Fig. 1 - a Alternaria alternata. b Alternaria solani. c Aspergillus niger. d Botrytis cineria. e Cladosporium fulvum. f Colletotrichum truncatum. g Curvularia tetramera. h Fusarium oxysporum. i Geotrichum candidum. j Mucor meucedo. k Penicillium notatum. 1 Phoma exigua. $\mathrm{m}$ Pythium aphanidermatum. n Phytophthora infestans. o Pullularia pullulans. $\mathrm{p}$ Rhizopus stolonifer. Photos identified by Pathology Unit, Central Department of Botany, T.U.

Table 1 List of obtained species with their characteristics.

\begin{tabular}{cll}
\hline S.N. & Name of the obtained species & Characteristics \\
\hline $1 . \quad$ Alternaria alternata & Conidiophores single or in small groups, simple or branched, \\
& straight or flexuous, olivaceous or golden brown, smooth, with \\
& conidial scars. Conidia formed in long chain 5-8, obclavate, \\
& obpyriform or ellipsoidal, with short, beak, pale or golden brown, \\
& smooth or verruculose with up to 8 transverse and usually several \\
& longitudinal or oblique septa. Beak pale. \\
\hline Alternaria solani & Conidiophores single or in small groups, simple or branched, \\
& straight or flexuous, septated, pale brown or olivaceous brown. \\
& Conidia usually solitary, or in a group of 2-3, straight or slightly \\
& flexuous, oblong or ellipsoidal tapering to a long beak, pale golden \\
& or olivaceous brown, smooth with 9-11 transverse and 0 or few \\
& longitudinal or oblique septa, beak flexuous, pale tapering gradually. \\
\hline Aspergillus niger & Conidiophore erect, straight or flexuous. Colorless or with the upper \\
& part brown, swollen at the apex into the spherical vesicle covered by \\
& closely packed more or less clavate branches. Flask shaped phialides \\
& present in a group at the apex of branches. Conidia catenate, dry \\
& usually globose brown verruculose or echinulate conidial heads at \\
& first globose, blackish brown to black, in age splitting into several \\
& loose columns.
\end{tabular}


Table 1 Continued.

\begin{tabular}{|c|c|c|}
\hline S.N. & Name of the obtained species & Characteristics \\
\hline 4. & Botrytis cinerea & $\begin{array}{l}\text { Conidiophores erect, unbranched or seldom branched, septate, wall } \\
\text { blackish-brown, toward the tip almost hyline with several projections } \\
\text { from which the conidia are formed singly on the very fine warts. } \\
\text { Conidia ovate or elliptical to almost globose, finely apiculate at the } \\
\text { base, with almost hyline, slightly brownish wall. }\end{array}$ \\
\hline 5. & Cladosporium fulvum & $\begin{array}{l}\text { Conidiophore macronematous, mononematous, caespitose, } \\
\text { unbranched or occasionally branched, straight or flexuous; narrow } \\
\text { near the base broadening at the unilateral nodes, pale brown or } \\
\text { olevaceous brown, smooth. Conidia catenated, frequently branched } \\
\text { cylindrical with rounded ends or ellipsoidal, } 0-3 \text { septed, hilum slightly } \\
\text { protuberant. }\end{array}$ \\
\hline 6. & Colletotrichum truncatum & $\begin{array}{l}\text { Conidia non-septate, hyline, falcate, truncate, uninucleate with oil } \\
\text { drops in the cytoplasm. Setae present in acervulus, telomorph present } \\
\text { i.e. Glomerella truncata sp. nov. }\end{array}$ \\
\hline 7. & Curvularia tetramera & $\begin{array}{l}\text { Mycelium branched septated sub-hyline or brown, conidiophores dark } \\
\text { olivaceous brown or very irregular; simple or compound. Conidia } \\
\text { produced at irregular distance from the base, chiefly } 4 \text { celled, born in } \\
\text { cluster of } 2-3 \text { to } 50 \text { or more; dark olivaceous to brown, rather } \\
\text { symmetrical shape tapering towards the rounded ends. Conidia with } \\
\text { basal hyline cell, produced on branched conidiophore. }\end{array}$ \\
\hline 8. & $\begin{array}{l}\text { Fusarium oxysporum var. } \\
\text { aurantiacum }\end{array}$ & $\begin{array}{l}\text { Macroconida large, curved, sickle-shaped/lunate in sporodochia and } \\
\text { pionnotes, usually } 4-5 \text { septed Presence of extended sclerotial bodies, } \\
\text { deep purple violet colored stroma. The fungus without aromatic odor. }\end{array}$ \\
\hline 9. & Geotrichum candidum & $\begin{array}{l}\text { Mycelium hyline, prostate forming turf, turf cushion like somewhat } \\
\text { powdery white. Hyphae prostate with few septa. Conidiophores short } \\
\text { and erect or ascending, septed producing conidia in chains at their } \\
\text { apex. Conidia short cylindrical, truncate at both ends hyline. }\end{array}$ \\
\hline 10. & Mucc & $\begin{array}{l}\text { Simple, unsepted mycelium, bearing erect, silvery grey shingling } \\
\text { unbranched, sporangiophore that produces non-apophysate, brownish } \\
\text { black, cylindrical or companulate spherical sporangia with red-orange } \\
\text { content. Elliptic or sub-cylindrical variable sized spores with smooth } \\
\text { wall tardily yellow or colorless. Zygospore spherical with black thick } \\
\text { varicose hard and fragile exine, enclosed colorless in tine. }\end{array}$ \\
\hline 11. & Penicillium notatum & $\begin{array}{l}\text { Well developed, copiously branched, septed hyphae. Conidiophores } \\
\text { usually arise from submerged mycelium, sometimes branched, } \\
\text { produce long heads; fructifications in two stages metulae and } \\
\text { phialides on which globose to oval, long chains of conidia are } \\
\text { produced successively. }\end{array}$ \\
\hline 12. & Phoma exigua & $\begin{array}{l}\text { Pycnidia globose to sub-globose or irregular with a non-papillate } \\
\text { ostioles glabrous solitary or confluent; membranous to leathery or } \\
\text { almost carbonous black. Conidiophore inside pycnidia insignificant. } \\
\text { Conidia, sub globose, ellipsoidal to oblong or allantoid, usually with } \\
\text { guttules mainly aseptate, maybe singly septed. }\end{array}$ \\
\hline 13. & Pythium aphanidermatum & $\begin{array}{l}\text { Coenocytic, aseptate, cylindrical and branched mycelium; septa } \\
\text { formed at the tip of hyphae to set sex organ; oogonia terminal, } \\
\text { globose and smooth. Antheridia mostly intercalary, sometimes } \\
\text { broadly shaped, } 2 \text { per oogonium, monoclinous or diclinous. Thick- } \\
\text { walled, aplerotic oospores and lobed sporangia that contain kidney } \\
\text { shaped, biflagellate zoospores. }\end{array}$ \\
\hline 14. & Phytophth & $\begin{array}{l}\text { Heterothallic and bisexual. Coenocytic, branched mycelium; septa } \\
\text { formed at the tip of hyphae to set sex organ; opaque, white lemon } \\
\text { shaped sporangia with papilla at distal end are borne singly on the } \\
\text { branch tips of alternatively branched sporangiophores that contains } \\
\text { zoospores. }\end{array}$ \\
\hline
\end{tabular}


Table 1 Continued.

\begin{tabular}{cll}
\hline S.N. & Name of the obtained species & \multicolumn{1}{c}{ Characteristics } \\
\hline $15 . \quad$ Pullularia pullulans & $\begin{array}{l}\text { Hyphae dark color with age composed of chains of dark, thick-walled } \\
\text { cells, connected by strands of lighter colored cells. Conidia as oval to } \\
\text { elongated cells, thick-walled and darkly pigmented budding from } \\
\text { brown, branching and septate mycelial threads, both terminally and } \\
\text { laterally, may continue to multiply by budding and abstriction. } \\
\text { Mycelial cells later divided into a number of isodiametric cells with } \\
\text { rounded sides and thick double wall, filled with oil drops. }\end{array}$ \\
\hline 16. Rhizopus stolonifer & $\begin{array}{l}\text { Simple, non-septed mycelium produces stolon which forms tufts of } \\
\text { sporangiophores; well-developed rhizoids attached at the point where } \\
\text { stolon are produced; sporangiophores bear large, spherical sporangia } \\
\end{array}$ \\
& with flattened base having well-developed hemi-spherical columella. \\
& Spores, round or oval, angular, colorless or brown with circularized \\
& wall. Zygospore naked. \\
\hline
\end{tabular}

Source: (Ellis 1971, Gilman 1998)

Table 2 Fungal species, the sites from which they were isolated, the category based on frequency of isolation and their corresponding diseases.

\begin{tabular}{|c|c|c|c|c|c|c|}
\hline S.N. & Name of Fungi & Site A & Site B & Site C & Category & Diseases \\
\hline 1. & Alternaria alternata & + & + & + & $\mathrm{D}$ & Back mold rot \\
\hline 2. & Alternaria solani & + & + & + & $\mathrm{D}$ & Alternaria rot \\
\hline 3. & Aspergillus niger & + & + & + & $\mathrm{D}$ & Back mold rot \\
\hline 4. & Botrytis cinerea & + & + & - & $\mathrm{M}$ & Grey mole rot \\
\hline 5. & Cladosporium fulvum & + & + & - & M & Scab/Cladosporium rot \\
\hline 6. & Colletotrichum truncatum & + & + & + & $\mathrm{D}$ & Anthracnose rot \\
\hline 7. & Curvularia tetramera & - & + & + & M & Drechslera mold rot \\
\hline 8. & Fusarium oxysporum & + & + & + & $\mathrm{D}$ & Fusarium rot \\
\hline 9. & Geotrichum candidum & + & + & + & $\mathrm{D}$ & Sour rot \\
\hline 10. & Мисот тисеdо & + & + & + & $\mathrm{D}$ & Mucor rot \\
\hline 11. & Penicillium notatum & - & + & + & $\mathrm{M}$ & Penicillium rot \\
\hline 12. & Phoma exigua & - & + & - & $\mathrm{R}$ & Phoma rot \\
\hline 13. & Pythium aphanidermatum & + & + & - & M & Pythium rot \\
\hline 14. & Phytophthora infestans & + & + & - & $\mathrm{M}$ & Phytophthora rot \\
\hline 15. & Pullularia pullulans & + & - & - & $\mathrm{R}$ & Russet \\
\hline 16. & Rhizopus stolonifer & + & + & + & $\mathrm{D}$ & Rhizopus rot \\
\hline \multicolumn{2}{|c|}{ Total numbers of species } & 13 & 15 & 10 & & \\
\hline \multicolumn{2}{|c|}{ Numbers of species in percentage } & $81.25 \%$ & $93.75 \%$ & $62.5 \%$ & & \\
\hline
\end{tabular}

\section{Conclusion}

Most of the pathogens associated with diseases were soil fungi that are transmitted from field or during harvesting, transportation and storage. Fungal pathogens directly or indirectly, infected the fruits and vegetables sold by traders. Therefore, consumers should be careful of fungal diseases and have knowledge about the symptoms of diseases. Well-managed vegetable markets should be facilitated by the local government and control measures must be applied by farmers and traders.

This study provides awareness of fungal disease of tomato to the public and will be helpful to build up a concrete strategy for management of postharvest fungal disease of tomato. As the study of diseases on tomatoes is important and concerned with public health, it is necessary to carry out such research works on tomato diseases. So, this investigation can be the base for further research in the future.

\section{Acknowledgements}

The authors would like to acknowledge Dean's Office of Institute of Science and Technology, Tribhuwan University for providing the research grant to conduct this study. The 
authors are obliged to the Central Department of Botany, Tribhuvan University for providing laboratory facilities. The Natural History Museum, Swayambhu, Tribhuvan University is thanked for facilitating the administrative asset. Sincere thanks are extended to the local traders of the study area for providing valuable information and materials for the experiment.

\section{References}

Adhikari MK, Manandhar VK. 1997 - Fungi of Nepal. Bista, M.S., Vaidya, Y. N., Adhikari, M. K. (Eds). Department of Plant Resources, HMG, Nepal. 2(60).

Agrawal GP, Nerne KG, Beliram R. 1950 - Fungi causing plant disease at Jabalpur, M P Proceeding of National Academy Science, India. 13, 310-315.

Ainsworth GC, Sparrow FK, Sussman AS. 1972 - The Fungi; an advanced treatise. Academic Press, New York. 4, 1-621.

Arx JA. 1974 - The Genera of Fungi Sporulating in Pure Culture. Strau $\beta$ \& J Cramer Germany.

Banyal DK, Mankotia V, Stigha SK. 2008 - Integrated management of tomato collar rot caused by Selerotitini rolfsii. Journal of Mycology and Plant Pathology. 38,165-167.

Barnett HE. 1960 - Illustrate Genera of Imperfect Fungi, (2nd edition). Burgess publishing Co. Min-Neapolis.

Bartz, Steven A, Sargent, Michael M. 2017 - Guide to Identifying and Controlling Postharvest Tomato Diseases in Florida. IFAS extension, University of Florida, HS866, U.S. Department of Agriculture, UF/IFAS Extension Service, University of Florida, IFAS, Florida A \& M University Cooperative Extension Program, and Boards of County Commissioners Cooperating. Nick T. Place, dean for UF/IFAS Extension. http://www.edis.ifas.ufl.edu (Retrieved on October 15, 2020).

Bessey EA. 1950 - Morphology and taxonomy of Fungi. Vikas Publishing House Pvt. Ltd. New Delhi.

Chigoziri E, John O, Nam NS. 2018 - Fungi associated with postharvest rot and seedling infection of tomato (Solanum lycopersicion) from Otukpo and Makurdi Local Government Areas of Benue State, Nigeria. In: Proceeding of 36th annual conference of horticulture society of Nigeria (Hortson).Faculty of Agriculture, Shabu Lafia Campus, Nigeria. pp. 641-645.

Climate Data. 2020 - Kathmandu Climate (Nepal). https://en.climate-data.org/asia/nepal/ (Retrieved on October 9, 2020).

Douglas B. 1922 - A new Alternaria spot of tomatoes in California. Phytopathology, 12,146-148.

Enyiukwu DN, Awurum AN, Nwaneri JA. 2014 - Efficacy of plant derived pesticides in the control of myco-induced postharvest rots of tubers and agricultural products: Net Journal of Agricultural science 2(1), 30-45.

Ellis MB. 1971 - Dematiaceous Hyphomycetes. Commonwealth Mycological Institute, Kew Survey, England 1-608.

George B, Kaur C, Khurdiya DS, Kapoor HC. 2004 - Antioxidants in tomato (Lycopersicum esculentum L) as a function of genotype. Food Chemistry. 84, 45-51.

Doi 10.1016/S0308-8146(03)00165-1.

Gilman JC. 1998 - A manual of Soil Fungi (second edition). Biotech Books. New Delhi.

Hahn F, Lopez I, Hernandez G. 2004 - Spectral Detection and Neural Network Discrimination of Rhizopus stolonifer Spores on Red Tomatoes. Biosystem Engineering. 89(1), 93-99.

Jofee AZ. 1986 - Fusarium Species: Their Biology and Toxicology. New York: John Wiley and Sons.

Kakde UB, Kakde HU. 2012 - Incidence of Post-Harvest Disease and Airborne Fungal Spores in a Vegetable Market. An International Journal Acta Botanica Croatica. 71 (1), 147-57.

Kohl J, Scheer C, Holb IJ, Masny S, Molhoek W. 2015 - Toward an integrated biological control by Cladosporium cladosporiodes $\mathrm{H} 39$ in apple scab (Venturia inequalis) management. Plant Disease. 99(4), 535-543. 
Manandhar C, Baidya S, Manandhar S, Pant B, Mahato BN. 2017 - Identification of Different Diseases of Tomato on Solanaceous Crops from Different Location of the Country. Proceedings of the 9th national horticulture workshop. 253-261.

Manandhar V, Adhikari MK, Pathak LN. 1997 - New Records of Fungi \& Hosts from Kathmandu Valley. Journal of Natural History Museum. 16 (1-4), 47-53.

Mascio P, Kaiser S, Seis H. 1989 - Lycopene as the most efficient biological carotenoid singlet oxygen quencher, Archives of Biochemistry and Biophysics, 274(2), 532-538.

Mills WR. 1940 - Phytophthora infestans on tomato. Journal of Phytopathology. 30,830-839.

Massoud MS. 2013 - Survey of Fungal Diseases of Some Vegetables and Fruits in Aswan, EGYPT. IOSR. Journal of Pharmacy and Biological Sciences. 6(3), 39-42.

Nelson PE, Burgess LW, Summerell BA. 1990 - Some morphological and physiological characters of Fusarium species in sections liseola and elegans and similar new species. Mycologia. 82, 99-106.

Rodrigues BB, Kakde UB. 2019 - Post Harvest Fungi Associated with Solanum Lycopercisum (tomato) Fruit collected from Different market of Mumbai. Online International Interdisciplinary Research Journal. 9, 52-60.

Sajad AM, Jamaluddin, Abid HQ. 2017 - Fungi Associated with the Spoilage of Postharvest Tomato Fruits and Their Frequency of Occurrences in Different Markets of Jabalpur, Madhya-Pradesh, India. International Journal of Current. Research and Reviews. 9(5), 12-15.

Shi J. 2008 - Lycopene in Tomatoes: Chemical and Physical Properties Affected by Food Processing. Critical Reviews in Biotechnology. 20(4). Doi 10.1080/10408690091189275.

Talvas J, Caris-veyrat C, Guy L, Rambeau M. 2010 - Differential effects of lycopene consumed in tomato paste and lycopene in the form of purified extract on target genes of cancer prostatic cells. American Journal of Clinical nutrition. 91, 1716-1724.

Wamache A. 2005 - Vegetable seeds handbook. Regina seeds Seminis. Printed by Bizone ltd. Nairobi Kenya, 23-25.

Wani AH. 2011 - An Overview of the fungal rot of tomato. Journal of Mycology and Pathology. 9(1), 33-38. 